\title{
Study on Teachers' New Roles in the Practice of College Foreign Language Layering Teaching from the Perspective of Effective Teaching*
}

\author{
Danting Sui \\ Jiangxi Institute of Fashion Technology \\ Nanchang, China
}

\author{
Jiawei Gu \\ Jiangxi Institute of Fashion Technology \\ Nanchang, China
}

\begin{abstract}
Effective teaching is one of the purposes of layering teaching in foreign languages. In the process of layering teaching, teachers play various and new roles, affecting students' development in many ways. The thesis mainly discusses teachers' new roles and countermeasure and suggestions for teachers' roles conversion.
\end{abstract}

Keywords-teacher's role; conversion; layering teaching; effective teaching

\section{INTRODUCTION}

Layering teaching has been being practiced in foreign language teaching in our college, Jiangxi Institute of Fashion Technology since 2016. The purpose of this teaching reform is to improve students' language abilities and teaching quality, realizing effective teaching.

Layering teaching in colleges or universities challenges the old traditional curriculum system a lot on its function, content and action. It requires teachers to change conventional teaching way and methods, establishing a new kind of teaching. Teacher is the critical element on whether the curriculum reformation succeeds and effective teaching realizes. Therefore, teachers should play new roles in the layering teaching.

\section{BASIS FOR TEACHERS' ROLES CONVERSION}

\section{A. Theoretical Basis}

1) Layering Teaching's basic conception:Teach students in accordance with their aptitudes. The learning performance of students with different abilities and different learning habits is extremely complicated. Teachers need to flexibly design their methods according to their aptitudes. It means that teachers should pay more and more attention to students. They need to know their students' learning habits, study on teaching strategies, inspire students' learning enthusiasm as well as motivate students to explore. The role of teachers is crucial.

2) Lifelong education: The theory of lifelong education

*Fund: The thesis is within the teaching-reform research of Jiangxi Institute of Fashion Technology's projects (Grant No.JF-LX-201703) holds that because human beings face with unprecedented challenges, the knowledge and skills learned by a person at a certain time can no longer be used for life, and they must continue to learn and develop themselves. Learning is not only a period of time and students cannot rely on teachers, which challenge the traditional teachers' role. Only by continuing to study can teachers solve the problems encountered in teaching in order to meet the needs of students for the diversity of teachers.

\section{B. Practical Basis}

1) Requirements of Guidelines on College English Teaching: Guidelines on College English Teaching points that goal of college English teaching is to develop students' English application ability, enhance cross-cultural communication awareness and communicative competence, develop self-learning ability, and improve comprehensive cultural literacy, so that they can use English effectively in learning, living, social interaction and future work to meet the needs of national, social, school and personal development. How to develop students' self-learning ability mostly depends on teachers' teaching methods, teaching level and teaching abilities. With the development of education and establishment of new teaching models, teachers should transform traditional roles to new ones to adjust themselves to new teaching environment.

2) Requirements of development of teachers' professional Competence: Based on the view of effective teaching in the layering teaching, foreign language teachers should study further on the teaching theories, students and teaching contents to improve self-profession knowledge, such as what the effective teaching and layering teaching are and how to teach students effectively in the layering teaching. Considering this, teachers need to focus on teaching reformation actively, figure out the related teaching ideas on their own, transfer old teaching conceptions and improve teaching abilities positively.

In our college, 50 teachers (13 foreign language teachers and 37 other professional teachers) were conducted a questionnaire survey about the relationship between teachers' roles and teachers' professional competence in 
March 6. From statistics, none of them does not agree that development of professional competence require teachers to change their roles and vice versa.

\section{TEACHERS' ROLES CONSTRUCTION IN LAYERING TEACHING PRACTICE}

\section{A. New Teachers' Roles in the Layering Process}

The layering teaching in our college adopts a kind of layered and mobile class teaching system. New students will be divided into three groups, which are primary, intermediate and high language-level groups, according to the scores in College Entrance Exam of foreign languages. The students with similar language-level will learn together in the same class. Layering process has been the main part of teaching job, so teachers also play new roles.

1) As instructors in the layering process: The layering teaching begins when the new students enter into the college. Most of them are confused and totally at a loss, because this is the first time for them to have the right to choose English or other foreign language subjects with different levels, which has never been practiced in high school. Even though course selection rules have been informed to students in advance, such as selecting course by their scores of College Entrance Exam of foreign languages and their willingness, it's difficult for them to choose suitable course. Last year, when I instructed students to choose course, I found some students with good foundation choose the primary course. It's strange, so I asked them the reason they didn't choose higher-level course, they told me it's easier to pass the final exam. However, they didn't realize they wouldn't learn more and improve their language ability at all. Though it's just one example, it shows students make a choice as they like, without long-term perspective. To help students make a right choice and be good for future teaching work, teachers need to be an instructor. Instead of telling students which language-level course they choose, they should be told differences among every course such as teaching aims, requirements, what they can get and difficulties they may meet.

I surveyed on this question: whether the teacher should instruct the students in selecting course. In the survey of 200 students who enrolled in 2017, 144 students chose to let teachers instruct them in selecting course, 32 students thought it doesn't matter whether there's a teacher or not, and 24 students hoped they can do it on their own. The proportion of each part is shown in chart 1 . The chart shows clearly that most students need teachers' instruction. It also means teachers need to play a role as an instructor.

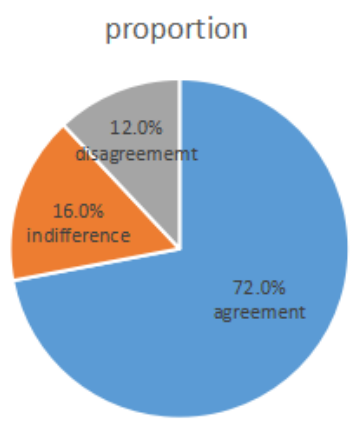

Fig. 1. Proportions of students on teachers' instruction.

2) As participants in the layering process: Besides being instructors, teachers should participate in layering process actively. Up to now, there is no uniform standard for the division of levels. Due to different student conditions, we must analyze the specific situation in the layering practice. Therefore, layering is not just a matter of students, but of teachers.

"Layering teaching based on the students' existing knowledge, ability levels and potential tendency, the teacher divides the students into several groups with similar levels and treats levels differently."(1) Teachers need to make standards of layering according to students' levels, set teaching goals for different English-level class and so on. For example, in our college layering practice, the division of levels mainly considers the following two aspects: the scores of College Entrance Examination in foreign languages and students' willingness, which have been discussed by all foreign language teachers. If not all teaching staff involves, the standard of division can't be decided. As for whether teachers should participate in layering process, I made a survey in the teaching staff, 13 foreign language teachers. Everyone's opinion is consistent. It shows teachers' role is more abundant.

Sometimes, teachers need to observe students' performance and their improvement. If they improve a lot or get higher grades in the final exam, teachers can recommend these students to higher level class. It's teachers' responsibility to remind students with great progress in study to choose course again after one year in order to get greater progress. The layering system is dynamic. It can be adjusted according to students' learning situation and needs. Though students choose course willingly, it doesn't mean teachers are just bystanders. Students choosing the course, which is the part of layering teaching, is just beginning.

\section{B. New Teachers' Roles from the Perspective of Students}

1) As guides on class: In the traditional class, because of limited time, it's impossible for teachers to guide students carry out class activities respectively. After layering, since students in the similar level have similar or consistent learning habits, cognitive ability and the way of thinking, teachers can give them one-time instructions and guidance to carry out activities. The difference among every level is how much guidance teachers give. Take summarizing the 
general idea of the paragraph for example. For the primary students, considering their weak foundation, teachers must lead them find key words together and explain difficult words. After leading students do it once or twice, they can finish the rest on their own. For the intermediate students, they can be told the procedures: find the key words and analyze the connections between sentences. For the higherlevel students, teachers can adopt flip classroom. Ask students to find out the ways to solve this kind of problems. Teachers in the layering class are guides, no longer talking and explaining language points all along.

2) As instructors in the change of students' roles: The aim of layering teaching is to motivate students to learn actively and positively and change their learning habits, so the students need to change their roles inside their hearts. They are the main body of layering teaching. They should be an active learner, independent learner as well as a learner who ask questions frequently. How to change students' roles in the study? Sometimes, they are not aware of this. Even though they know it, they don't know how to do and what to do. Therefore, teachers come to be instructors in the change of students' roles. Teachers need to tell students their position and their roles on the foreign language layering class, help students know the importance of their roles and encourage them to change slowly.

3) As providers for students' needs: What do students need in layering teaching? Besides knowledge, they also need to know more about the practice of layering teaching in the colleges, like layering standards, layering tests, its characteristics, teaching aims and requirements. They are exposed to this teaching model for the first time, so teachers have to provide more information for students. Students also need more learning strategies to get into higher level class. For each teacher, they may teach students in different levels, thus they should provide different learning strategies. For the primary-level and intermediate-level students have the poor ability to collect learning materials on Internet, teachers had better provide some useful and helpful websites for them.

\section{New Teachers' Roles from the Perspective of the Curriculum}

1) As developers of curriculum: Foreign languages are all second languages in China. In most areas, people seldom use second languages in their daily lives, so in language teaching, teachers are treated as tool of curriculum. They are merely the mediators of the spread of books' knowledge. Even though teachers want to change this situation and integrate teaching materials, it's impossible for them to do this because students' levels of the language are obvious different. However, in the layering teaching, we have to do some changes.

From a microcosmic point of view, there's no one book suitable for a certain level of students. At the same time, layered and mobile class teaching system just begins in colleges and universities, so curriculum in this system is not perfect. Taking these two aspects into account, teachers have to be the developer of curriculum resources. They need to reorganize curriculum resources suitable for students they teach and focus on language points fit for students to accept. If necessary, they need to add some teaching materials according to students' requirements.

From a microscopic point of view, teachers should develop the curriculum from aspects of curriculum objectives, content, implementation and evaluation. Curriculum objectives are determined through demand analysis. Then according to this goal, the teaching content and related teaching activities of a certain discipline (or multiple disciplines) are selected to be planned, organized, implemented, evaluated and revised.

2) As selectors of courseware: Courseware does help teachers a lot on the teaching. In the process of integration of courseware and subject teaching, teachers still have many misunderstandings about the use of courseware. Teachers can use it on class to save time and make knowledge appear more concrete and direct. At least in our college, every teacher uses PPT on each class. The core feature of information technology should be aiding, that is, assisting teacher teaching and assisting student learning. However, using the courseware as the center to teach, teachers will not be able to regulate the classroom according to the actual situation of the students and deviate from the main body of the teaching. This type of teaching can easily lead students' fails to learn and influence badly on actual teaching.

In addition, for most books' course wares, they are provided directly by the publishing house. If there is a lack of analysis of the characteristics of learners, using it blindly may cause students to learn inappropriate, because most of the courseware we use directly is designed for students with a high level of cognition, they often dazzle students and eventually become over-emphasized and lose their value. In order to make the multimedia courseware truly effective, teachers should select courseware and be a selector.

\section{COUNTERMEASURE AND SUGGESTIONS FOR TEACHERS' ROLES CONVERSION}

\section{A. Inner Cause}

1) Increase awareness and change thinking: The layering teaching reform is carried out in order to improve the quality of education and achieve effective teaching, meeting diverse and varied needs of students. On the reform road, universities and their internal members will meet all kinds of problems. Therefore, colleges and their internal members must firmly resolve the determination and confidence of reform, and have a deep understanding of reform. The road to the revolution is twisty, but the future is bright.

The transformation of teacher roles is an important part of the reform. Whether the teacher's role meets the requirements of the layering teaching system affects the implementation of the reform. Teachers must raise 
awareness, realize the importance and necessity of their roles' transformation and prepare conversion from their inner hearts. Only ideological acceptance and correct understanding help teachers successfully complete the roles' conversion.

2) Enrich professional knowledge: In today's world, the science and technology is developing rapidly. Advances in science and technology provide technological various means for the study of foreign languages, and new ideas and new achievements have also emerged. Therefore, if foreign language teachers fail to keep up with the pace of the times, and do not actively update the knowledge structure and transform roles, they will certainly be eliminated by the times. Therefore, teachers must constantly improve their professional standards, carefully study the requirements of new curriculum standards and new content in textbooks and clarify the knowledge structure of foreign languages. On this basis, the knowledge is constructed and applied to specific teaching roles' conversion.

\section{B. External Cause}

1) Carry out training activities: Colleges should actively carry out teaching and training activities for foreign language teachers, and support them to actively participate in advanced training.

On the one hand, before teachers enter the new terms, colleges should take time out and organize teachers to preservice training. It is very important for teachers after vacation. It allows teachers to learn new theoretical knowledge and how to apply it in practical teaching. Through training, teachers can get into jobs and enter the teachers' roles quickly.

On the other hand, the college-based training mechanism has been effectively improved to enhance the literacy of teachers. Off-campus training focuses on the training of educational theory knowledge. It can't give guidance advice on actual problems in the layering teaching. It is difficult to mobilize the enthusiasm of teachers. Therefore, colleges should promote and improve college-based training.

2) Establish reward system: In the process of teachers' role transformation, due to the differences in teachers' understanding of roles, personal attitudes and abilities, the effect of their role conversion will be different. Colleges need to assess the effectiveness in the teacher role conversion and reward teachers based on the assessment results.

The reward system mainly includes material rewards and spiritual rewards. Material rewards give teachers direct material benefits. It is a material reward for teachers' hard work. Even though spiritual rewards don't be seen, it gives teachers spiritual pleasure and satisfaction. It is a spiritual encouragement for teachers to transform their roles hard. With material and spiritual rewards, teachers have more motivation to change role and are more willing to perform role transitions.
Rewards are not the ultimate goal, but rewards can prevent teachers from giving up their roles transformation when they meet the difficulties and hassle in changing roles. In addition, the reward system reflects the spirit of the college's humanistic care. Colleges can gain more support and the culture atmosphere can be more harmonious.

\section{CONCLUSION}

Teachers have been regarded as noble and great. The nobleness and greatness of the teacher profession is not only reflected in the selfless dedication, but also reflected in the teacher's constant advance with the times. Teachers' roles should be transformed constantly with the reform of teaching.

Though this thesis mainly discusses some new teachers' roles in the layering teaching, not all aspects, I hope it can provide a kind of teaching reference and practical guidance for the majority of teachers.

However, due to the limitations of some subjective and objective conditions, the scope of the study is mainly in our college, so the number of questionnaires is too small. Moreover, the research on layered teaching in our college still belongs to the initial stage, and the layering implementation time is short, so the research on the role conversion of teachers needs to be further studied.

\section{REFERENCES}

[1] Danting Sui, Fenhong Li,Study on the Layering Teaching Model in College English, Proceedings of the 2nd Intenational Conference on Judicial, Administrative and Humanitarian Problems of State Structures and Economic Subjects (JAHP 2017)[C] ATLANTIS PRESS, 2017, Volume 159, P76.

[2] Albanese,M. A.\& Mitchell,S. Problem-based Learning:A Review of Literature on its Outcomes and Implemengation Issues[J].Acad Med,1993,Vol.68(1).

[3] Gardner, Howard, Intelligence Reframed: Multiple Intelligences for the 21st Century, Basic Books, 1999, P33-34. 